\title{
Quality Instruction as a Motivating Factor in Higher Education
}

\author{
Olusegun A. Sogunro ${ }^{1}$, Ph.D. \\ 1 Professor of Educational Leadership, School of Education and Professional Studies, Central Connecticut State \\ University, 1615 Stanley Street, New Britain, CT 06050, USA \\ Correspondence: Olusegun A. Sogunro, Ph.D., Professor of Educational Leadership, School of Education and \\ Professional Studies, Central Connecticut State University, 1615 Stanley Street, New Britain, CT 06050, USA
}

Received: July 12, 2017

Accepted: August 10, 2017

Online Published: August 17, 2017

doi:10.5430/ijhe.v6n4p173

URL: https://doi.org/10.5430/ijhe.v6n4p173

\begin{abstract}
The importance of quality instruction in motivating students in higher education cannot be overemphasized. Without quality instruction, students' motivation to learn recedes. Five focus groups of graduate students aided the data collection for this study. More than one-third of the 119 participating graduate students involved in this study claimed that quality of instruction was the raison d'être for their motivation in higher education. The implications of quality instruction for practice (i.e., andragogical competency, adequate preparation and organization, content and currency of knowledge, technological competency, resourcefulness, and dispositional attributes), institutional policy, and further research are also discussed.
\end{abstract}

Keywords: Motivation, Quality instruction, Higher education, Graduate students, Andragogy, Pedagogy

\section{Introduction}

In any learning endeavor, the success of students is the joy of the teacher. As educators, we take pride in the success of our students and always feel elated when we hear success stories of performance or accomplishments. Contrarily, students get dissatisfied when they receive a mediocre instruction that fails to inspire them and tends to be a waste of their time and money. Poor quality instruction is even more frustrating to students who have less time and resources to commit to their studies.

How to motivate students in higher education has been the focus of investigation for many years. However, most of these investigations have generally been focused on factors of motivation and/or barriers to motivation (Brookfield, 1986, 2006; Cranton, 1992; Knowles, 1980; MacKeracher, 2004; Merriam, Caffarella, \& Baumgartner, 2007; Wlodowski,1985, 1999, 2003). Unlike several other studies, this study focuses on the quality of instruction as a single most important motivating factor for students in higher education.

Bess (1997) asserts that "The effectiveness of any system of higher education is contingent in some considerable measure on the quality of the teaching enterprise" (p. ix). What is learned and how much is learned, depend importantly on the quality of instruction rendered by the faculty (Bess, 1997). Out of the eight motivating factors rated by 119 adult learners in a master's program in educational leadership at Central Connecticut State University, CCSU (i. e., quality of instruction, quality of curriculum, relevance and pragmatism, interactive classrooms and effective management practices, progressive assessment and timely feedback, self-directedness, conducive learning environment, and effective academic advising practices), the quality of instruction emerged as the most valued motivating factor in their higher education studies.

\section{Literature Review}

As noted by Schunk, Pintrich, and Meece (2008), motivation of students in higher education is a contagious phenomenon between learners and instructors. While motivated learners display interest in learning activities; feel self-efficacious; expend efforts to succeed; and persist at tasks; instructors are motivated to help learners learn, put extra time into instructional planning, and work with learners to help ensure their learning and mastery of knowledge, skills, and desired attitudes. In his study of college students, Perry (1991) asserts that the success of college students facing personal, academic, and societal challenges is dependent on two most salient factors-"the attributes they bring with them to the classroom and the quality of instruction they receive" and that "the ways in which the different instructional methods are used and implemented by the instructor can have dramatic effects on student motivation" (p. 1). Affirming the fact that learners bring to the classroom, attributes and dispositions that affect their 
ability to learn, Hattie (2012) encourages an instructor's recognition and use of these characteristics toward learners' motivation to learn.

Csikszentmihalyi (1997) believes that higher education succeeds or fails in terms of student motivation and that the product of teaching is an intrinsically motivated learner. In his research on Intrinsic Motivation and Effective Teaching, Csikszentmihalyi (1997) proposed two critical questions: "If the product of teaching is a student who enjoys learning, what are the means by which a teacher can accomplish this purpose? How does one get students to enjoy learning?" (pp. 72-89). Obviously, the main answer to these thought-provoking questions is simply "motivation," and more particularly motivation through "quality instruction."

While it is true that both adults and children are involved in learning processes, the nature of the instructional processes is qualitatively different (Merriam et al., 2007). Knowles (1980) distinguishes between andragogy (the art and science of helping adults learn) and pedagogy (the art and science of helping children learn). Perhaps because of the unique characteristics of adult learners, they require instructors with special attributes. Wiseman and Hunt (2001) posit that effective teachers are always competent in their approaches to teaching and "are able to motivate students or establish environments in which motivated students are the end result" (p. 10).

Instructor's inadequate teaching proficiency in higher education has also been identified as a critical factor affecting students' motivation to learn (Knowles, 1989; Knowles, Holton, \& Swanson, 2005; Perry, 1991; Thompson \& Clayton, 2004). As claimed by Perry (1990), the effectiveness of teaching has been the object of debate in higher education for centuries with much of the concerns coming from instructors who are neither expert in pedagogy nor andragogy. In other words, most instructors at colleges and universities lack preparation in the knowledge, skills, and attitudes of teaching adults. Rather, they learn the art of teaching adult learners more on the job.

On a broad spectrum, quality instruction embraces the soundness of all teaching and learning transactions in the classroom. It manifests itself in the use of appropriate instructional strategies to evoke enduring learning. In this paper, quality instruction is defined as the degree to which an instruction is adequately delivered, meets students' learning needs, learning styles, interests, expectations, and is well aligned to standards. It is a composite of andragogical competency, adequate preparation and effective organizational skills; currency of knowledge of content; technological competency, resourcefulness, and instructors' dispositional attributes (see Figure 1 and further discussion later in this paper).

\section{Methodology}

\subsection{Participants}

The 124 graduate students from five graduate classes that I taught in spring and summer 2009 at Central Connecticut State University constituted the five focus groups involved in this study. Demographically, a total of 23 (18.5\%) of the respondents were male and $101(81.5 \%)$ were females. Their ages were from 21 and up and they all had a minimum of Bachelor's degree or its equivalent. At the time of data collection in spring 2009, 28 of the students were enrolled in Supervision course, 27 in Administration course, and 24 in Leadership for Culturally Diverse Schools course. In summer 2009, 23 and 22 students were enrolled in Research in Education course, Sessions I and II, respectively.

\subsection{Data Source and Analysis}

An open-ended questionnaire, five focus group discussions (i.e., in five classes), and 13 nonstructured follow-up interviews (one-on-one interviews), were used to collect data for this study. In all classes, it was announced that participation was optional and that participants could opt out of the study at any stage. In spring and summer semesters of 2009, the open-ended questionnaire consisting of the eight motivating factors identified in an earlier study by the research (Sogunro, 2015) was administered to the 124 graduate students with a return rate of about $96 \%$ (i.e., 119 respondents). The choice of these five classes as focus groups was purposeful (because they were all graduate students and they suit the purpose of my study) and convenient (because they were all in the same classes and interested in participation). According to Gall, Gall, and Borg (2003), "the researcher selects a sample that suits the purposes of the study and that is convenient" (p. 175). Also, "In convenience sampling the researcher selects participants because they are willing and available to be studied" (Creswell, 2008, p. 155). On the average, the focus groups used in this study were relatively larger in size than typical focus groups of 8-12 participants (McMillan \& Schumacher, 2010) simply because each class was taken as a focus group.

Based on individuals' perspectives, participants were asked to rank order the eight motivating factors as well as explain their choices as much as they could. Data collection from each of the focus groups took between 60 and 90 minutes. Two or three students (i.e., for a total of 13) from each focus group were engaged in one-on-one follow-up 
interviews. These ranged from 15-30 minutes. Discussion highlights from each of the focus group sessions and interviews were noted and recorded in a notebook. Transcripts were content-analyzed by using codes, theming, frequency counts, and percentages. Respondents' choices were tallied and their percentages calculated (see Table 1). As shown in the Table, about $40.3 \%$ (i.e., 48 out of 119) of the participants rated quality instruction as having the greatest motivating influence on their studies.

\section{Findings and Discussions}

As shown in Table 1, quality instruction was ranked highest in four focus groups and third in one. A closer look at the Table further shows that in each of the focus groups, quality instruction ranked only between the third most important and the top most important and never in the lower half of the eight motivating factors. In the focus group in which quality instruction was ranked third, it had a frequency of 5 while relevance and pragmatism and quality curriculum tied for the first position with a frequency count of 6 each. On average, this means that the students generally cherished the efficacy of quality instruction as a superior motivating factor in their studies.

Table 1. Focus Group Survey Results

\begin{tabular}{|c|c|c|c|c|c|c|c|c|c|c|c|c|}
\hline \multirow[t]{2}{*}{ Motivating Factors } & \multicolumn{2}{|l|}{ A } & \multicolumn{2}{|l|}{ B } & \multicolumn{2}{|c|}{$\mathrm{C}$} & \multicolumn{2}{|c|}{$\mathrm{D}$} & \multicolumn{2}{|c|}{$\mathrm{E}$} & \multicolumn{2}{|l|}{ Total } \\
\hline & $\begin{array}{c}\mathrm{f} \\
(25)\end{array}$ & $\%$ & $\begin{array}{c}\mathrm{f} \\
(27)\end{array}$ & $\%$ & $\begin{array}{l}\mathrm{f} \\
(22)\end{array}$ & $\%$ & $\begin{array}{l}\text { f } \\
(23)\end{array}$ & $\%$ & $\begin{array}{l}\mathrm{f} \\
(22)\end{array}$ & $\%$ & $\begin{array}{l}f \\
(119)\end{array}$ & $\begin{array}{l}\% \\
100\end{array}$ \\
\hline $\begin{array}{l}\text { 1. Quality of } \\
\text { Instruction }\end{array}$ & 10 & 40 & 12 & 44.4 & 5 & 22.7 & 10 & 43.5 & 11 & 50 & 48 & 40.3 \\
\hline $\begin{array}{l}\text { 2. Relevance \& } \\
\text { Pragmatism }\end{array}$ & 5 & 20 & 2 & 7.4 & 6 & 27.2 & 3 & 13 & 2 & 9.1 & 18 & 15.1 \\
\hline $\begin{array}{l}\text { 3. Quality of } \\
\text { Curriculum }\end{array}$ & 4 & 14 & 3 & 11.1 & 6 & 27.2 & 2 & 8.7 & 3 & 13 & 18 & 15.1 \\
\hline $\begin{array}{l}\text { 4. Interactive } \\
\text { Classroom }\end{array}$ & 2 & 8 & 3 & 11.1 & 1 & 4.5 & 1 & 4.3 & 4 & 18.1 & 11 & 9.2 \\
\hline $\begin{array}{l}\text { 5. Progressive } \\
\text { Assessment \& } \\
\text { Timely } \\
\text { Feedback }\end{array}$ & 2 & 8 & 3 & 11.1 & 1 & 4.5 & 2 & 8.7 & 2 & 9.1 & 10 & 8.4 \\
\hline $\begin{array}{l}\text { 6. Self-Directedne } \\
\text { ss }\end{array}$ & 1 & 4 & 2 & 7.4 & 0 & 4.5 & 2 & 8.7 & 1 & 4.5 & 6 & 5.0 \\
\hline $\begin{array}{l}\text { 7. Academic } \\
\text { Advising } \\
\text { Practices }\end{array}$ & 0 & 0 & 1 & 3.7 & 2 & 9.1 & 1 & 4.3 & 0 & 0 & 4 & 3.4 \\
\hline $\begin{array}{l}\text { 8. Conducive } \\
\text { Learning } \\
\text { Environment }\end{array}$ & 1 & 4 & 1 & 3.7 & 1 & 4.5 & 0 & 0 & 1 & 4.5 & 4 & 3.4 \\
\hline
\end{tabular}

Note. A, B, C, D, E represent the five focus groups involved in the study.

From the perspectives of the 119 participating graduate students as shown in the Table, quality instruction, relevance and pragmatism, and quality curriculum were the three most highly rated motivating factors. While relevance and pragmatism, and quality curriculum were tied in the second position with 18 students each (15.1\%), quality instruction emerged in the first position with 48 students (40.3\%). That is, students' motivation to learn is aroused equally by the quality of curriculum and relevance and pragmatism, but more highly by the quality of instruction. This also means that students' inclination to be motivated by any of the eight motivating factors was twice as much for quality instruction than either quality curriculum or relevance and pragmatism. That is, students' learning is high when motivation is high and motivation is high when quality of instruction is high.

\subsection{Students' Understanding of Quality Instruction}

Based on content analyses, the following is a list of participants' responses (both from the survey and group discussions) to the question "What do you understand by quality instruction?"

- Quality instruction means an instruction delivered by a competent instructor rooted in content, facilitating the discovery and depth of new knowledge by students in a 
constructivist manner.

- Quality instruction means that the teacher can effectively engage students in the learning process and relay relevant knowledge. It does not only consist of lecturing to students or reading slides from a PowerPoint. A quality instruction should be dynamic — using different delivery styles.

- Quality instruction means the delivery of an instruction in a way that evokes students' interest, critical thinking, and learning in a meaningful way. It makes students become curious and excited about what they are doing and consequently enabling them to discover learning and take ownership of their own education.

- Quality instruction encompasses the use of cutting edge research and modern technology to aid teaching and learning.

- Quality instruction is one that is facilitated by an expert in the content area, uses best teaching practices and has clear and high expectations for students, and be able to relate theory to practice.

The foregoing explications constitute a manifestation of students' understanding of the effect of quality instruction on their motivation to learn.

\section{Implications}

The discussions of the implications of this study are three-pronged-implications for practice, institutional policy, and further research.

\subsection{Implications for Practice}

This study's implications for practice revolve around the "Composite of Quality Instruction" (Figure 1) which is an integration of distinct integrating factors or parts with overlapping functions. It includes andragogical competency; adequate preparation and effective organizational skills; content and currency of knowledge; technological competency; instructor's resourceful ability; and instructors' dispositional attributes. Functionally, each part works synergistically with other parts to engender a quality instruction. These parts were identified by the participants in this study.

Competency in andragogy. The basic principle of teaching known to most instructors in higher education today is pedagogy, hence a chronic challenge to quality teaching in higher education is an instructor's limited repertoire in andragogical principles. Other than the education received in their content areas, most instructors at colleges and universities lack the skills in teaching adult learners in higher education. As noted by Cranton (1996), an instructor's content expertise is not enough a prerequisite for teaching in higher education. An 


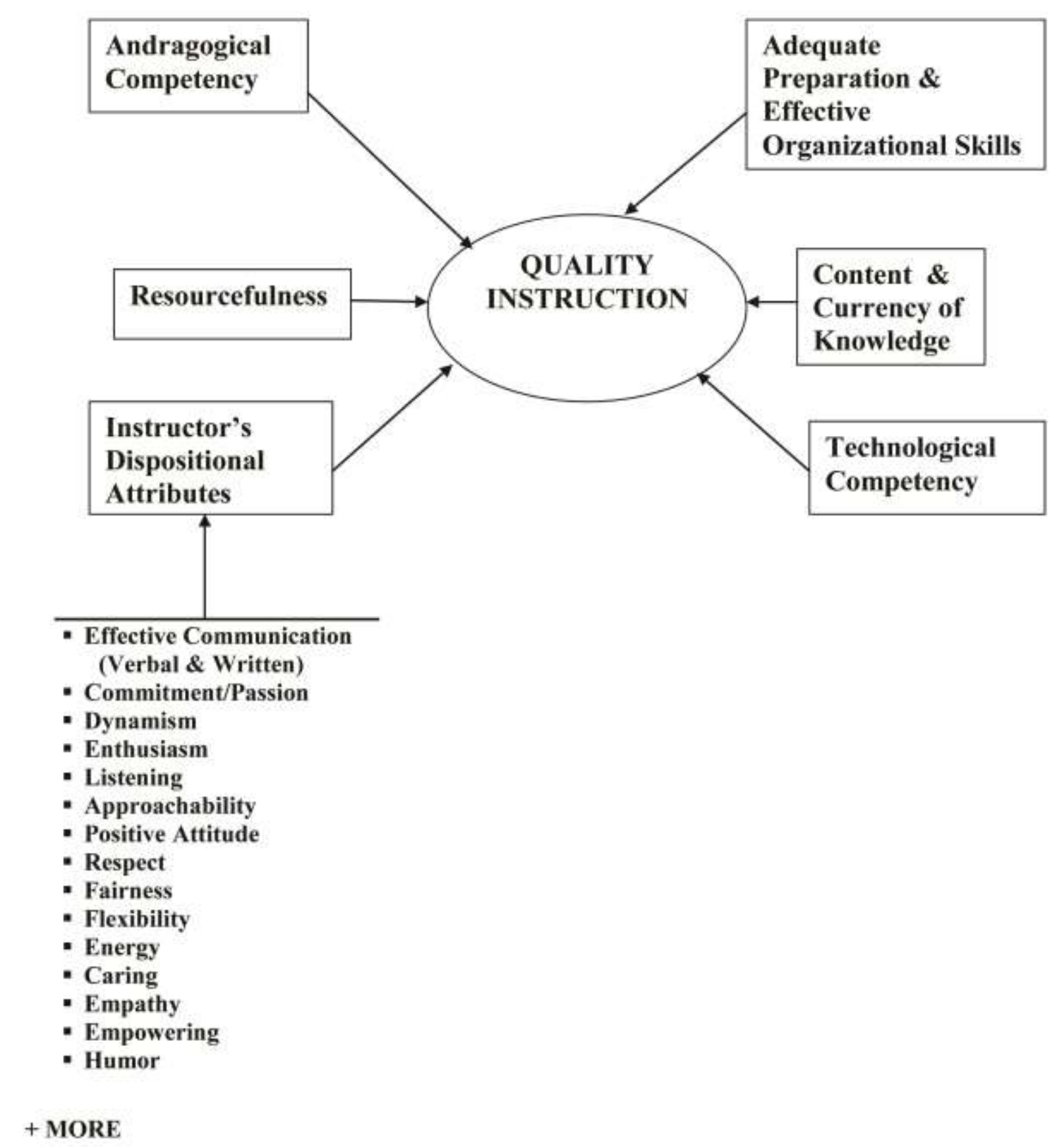

Figure 1. A Composite of Quality Instruction

instructor's "growth and development tend to come from experience and trial-and-error practice" (p. xi). The effect of an instructor's limitation in adragogical principles on adult learners' motivation cannot be underestimated.

An instructor's lack of andragogical skills often manifests itself in students' expression of dissatisfaction with quality of instruction delivered, students' withdrawal from the class and/or program transfer to another session, program or institution. The following comments from students during interviews are self-explanatory:

- Some professors teach us like high school students. This is a college and we are no longer adolescents, we are adults! I expect professors to use different teaching methods and treat us differently as being more responsible for our own learning. 
- Not all professors are the same. . . Those who really have passion for teaching adults tend to care better about the emotional baggage adult learners bring with them to the classroom.

- Do you think some professors know how to teach adults?

As explained by Knowles et al. (2005), the basic concern of instructors with a pedagogical orientation is content. They are "strongly concerned about what needs to be covered in the learning situation; how that content can be organized into manageable units; the most logical sequence for presenting these units; and the most efficient means of transmitting this content" (p. 295). In contrast, the basic concern of instructors with an andragogical orientation is process. They are strongly concerned with the andragogical process which consists of eight elements:

- preparing the learners,

- considering the physical and psychological climate setting,

- involving the learners in planning for their learning,

- involving the learners in diagnosing their own need for learning,

- involving the learners in formulating their own learning objectives,

- involving the learners in designing learning plans,

- helping the learners carry out their learning plans, and

- involving the learners in evaluating their own learning outcomes. (Knowles et al., 2005, p. 295)

In view of the fact that higher education institutions are basically dependent on adult learners, instructors, regardless of their specializations should be acquainted with knowledge and skills in andragogy.

Adequate preparation and effective organizational skills. It is not difficult to know an instructor who is well prepared and organized to teach a course. Adequate preparation and organizational skills manifest themselves in various ways, including clarity of syllabi and expectations, interesting and educative mode of delivery (i.e., 'capturing of audience' attention), use of adequate pacing and transitions, relevant classroom activities, clear assessment rubrics, and effective classroom management practices. Usually, before the first class meeting, an effective instructor is curious to know who the students will be and how to motivate them. According to Perry (1991), "Knowing that some students are career-oriented and highly motivated, while others are apathetic and disinterested, can have a strong bearing on the instructional practices adopted" (p. 1). Perry concludes that "The task for educators and researchers alike is to understand these matches so that instruction can be optimized for various subgroups in a college classroom" (p. 2).

Content and currency of knowledge. In any teaching and learning transactions, knowledge of content is a given for a professional teacher, hence, instructors at colleges and universities are often grounded in one content area or the other at the time of appointment. However, the currency of knowledge and skills in content areas can be very exciting and motivating for students. Indeed, currency of knowledge manifests an instructor's scholastic aptitude and passion for quality teaching.

Since recruitment, some faculty members have not changed their instructional practices. Interestingly, they teach the same courses year after year and are not sensitive to the changing times and increasing learners' diversity in terms of learning needs and styles. This approach stifles learners' motivation to learn. As observed by Stetar and Finkelstein (1997), in situations where instructors make a career at a single institution, they tend to add sameness of setting to the sameness of activities; and for many senior faculty who have been engaged in routine teaching assignments and who are relatively less involved in scholarship, there is little sense for change in their instructional practices. This practice is not motivating to students in higher education. Students in higher education generally think that the use of research makes their learning more authentic, increases their credibility of information received and their motivation to learn through discovery as well as ensures that their knowledge is up to date (Breen \& Lindsay, 1999; Jenkins, 2000; Lindsay, Breen, \& Jenkins, 2002). Therefore, instructors in higher education should be encouraged to embark on research activities that are relevant to their teaching.

Technological competence. Among other things, the use of computer applications has been noted to sustain students' motivation to learn, develop their critical thinking skills, and enhance their active participation in classroom activities. Since today's higher education students are growing in the information age and rampant use of digital devices, the need to use cutting edge technological gadgets or computer applications for teaching has more than ever before 
become a challenge for instructors. As remarked by Knowles et al. (2005), "In no dimension of education have there been more explosive developments in recent times than in educational media" (p. 119).

In enhancing adult motivation to learn in the digitally-oriented learning environment of today, emerging literature encourages the juxtaposition of the traditional instructional approach and technology. The report from Project Tomorrow (2011) proposes the use of mobile learning, online media, blended learning and e-textbooks as trends to motivate students' learning. Tucker (2013) refers to blended learning as a form of learning that integrates technology with traditional face-to-face instruction. That is, it combines on-ground learning with online learning, and in part, allows students to control the time, pace, and place of their learning. According to Mujiyanto (2013), blended or hybrid learning environments typically involves components of distance learning and a traditional face-to-face teaching. It is a hybrid between what Woodall (2012) referred to synchronous (traditional classrooms) and asynchronous (online or computer-based) domains of instructional methods.

However, the use of blended learning approach of instructional delivery raises a host of questions. One particular question relates to the nature and quality of interaction between instructors and students. In a study, "Comparing the Effectiveness of Classroom and Online Learning: Teaching Research Methods," Anna Ya Ni (2013) concluded that in online classes, participation may be less intimidating between individuals, has less time pressure on students, and the quality and quantity of interaction between instructors and students may be increased. Basically, the emotional bonds and the face-to-face rapport that build up quickly in on-ground settings become decreased as you move into the online mode. Whereas, the spontaneity or frequency of interactions between instructors and students increases in the online mode (Davidson-Shivers, 2009; Walter Gudea, 2008; Ya Ni, 2013).

One of the long term effects of blended learning on students' approaches to their studies is the increasing preference for hybrid learning. Adult learners are becoming more receptive of blended learning because it is more motivating, especially by appealing to their diverse needs and learning styles. Also, it makes learning more in-situ. That is, learners can sit in the comfort of their homes to learn and merely go to the traditional classroom for hands-on activities and/or face-to-face feelings of human interactions. By expanding accessibility to education, blended learning tends to motivate more adults to want to learn in a more convenient fashion than the traditional face-to-face classroom. With considerable increase in blended learning in higher education today, adults are exposed to different learning programs and experiences and have the liberty to decide what, when, how, and where to learn.

From an empirical standpoint, a key to an effective use of a blended learning approach is the instructor's ability to motivate student learning through a well-organized teaching-learning setting that encourages continuous interactions and stimulation of discussions between the instructor and students. Noting the ever changing technological innovations in teaching and learning transactions in higher education thereof, the key implication is for colleges and universities to continuously invest in the technological advancement of their faculty through various in-service workshops and training programs.

Resourcefulness. The use of a variety of resources to aid teaching and learning can be motivating to adult learners. Perhaps because students have different learning styles; resources that relate to different senses (i.e., touch, sight, smell, taste, and feelings); and Howard Gardner's nine multiple intelligences-linguistic, logical-mathematical, spatial, bodily-kinesthetic, musical, interpersonal, intrapersonal, naturalistic, and existentialist (Armstrong, 2009) have been known to arouse students' interest, increase motivation and make learning experience more authentic. Theorists and humanistic psychologists agree that the richness and accessibility of resources are crucial to effective learning (Knowles et al., 2005). According to this trio, "Provision of a basic learning resources center with books, pamphlets, manuals, reprints, journals, films, film strips, slides, tapes, and other audiovisual aids and devices is a minimal requirement" (p. 119). Fundamentally, the strategic use of various learning aids or multimedia are effective in changing the focus, pace, and transitions of an instructional delivery as well as enhancing students' retention of information and motivation to learn.

Instructors' dispositional attributes. Instructors in colleges and universities perform a variety of functions, including teaching, research, advising or mentoring, counseling, role modeling, and various services to the university community and the society at large. Research has shown that personal qualities of instructors or facilitators involved in the teaching and learning transactions are important in motivating adults to learn (Bess, 1997; Blackburn, 1997; Feldman, 1989; Rodgers, 1989; Schunk et al., 2008; Wiseman \& Hunt, 2001). Perhaps because of the multiplicity of roles, instructors have the largest amount of interactions with students; hence they tend to have the most influence on their learning. Moreover, because motivation is contagious, an instructor who is motivated to teach has the tendency of getting students motivated to learn. As gathered from the focus group discussions in this study, the following are some of the students' preferences for instructors' dispositional attributes: effective 
communication (verbal and written), commitment (or passion), dynamism, enthusiasm, listening, approachability, positive-attitude, respect, fairness, energy, flexibility, caring, empathy, empowering, and humor (see Figure 1).

Basically, effective communication is fundamental to quality instruction. Since communication is never effective without the receiver comprehending a sender's message, instructors must always endeavor to make their delivery of content as clear and fluid as possible so that students can find their teachings as meaningful learning experiences. An instructor's effective communication skill connotes the power of language of expression that is clear and meaningful to the learner. In their study titled "Investigating Your Own Teaching," D'Avanzo and Morris (2008) involved a range of instructors from various institutions of higher education in what they called practitioner research with the goal to enable instructors "to develop a much clearer understanding of what they really want their students to learn - and whether their teaching practice accomplishes those objectives" (p. 43).

Enthusiasm was another attribute identified by the respondents. According to Wlodkowski (1985), "an enthusiastic instructor is a person who cares about and values his subject matter and teaches it in a manner that expresses those feelings with the intent to encourage similar feelings in the learner. . . Emotion, energy, and animation are outwardly visible in this person's instruction (p. 29). Flexibility was another preferred characteristic for an effective instructor. As identified by the respondents and noted by Knowles (1984), "an essential feature of andragogy is flexibility" (p. 418), therefore, it becomes imperative for instructors to be as flexible as possible in attempts to catering to the varying needs of all learners. Furthermore, as discussed in the focus groups, students prefer instructors who are dynamic in using diverse teaching approaches and materials. They also admire instructors who are empowering and manifest respect, fairness, and positive attitude toward them and make them believe in themselves that they can achieve success in their learning endeavors.

As noted by Goleman (1995), humor expressed through good moods, jokes, laughing or elation can be motivating. Among other things, it "helps people think more broadly and associate more freely, noticing relationships that might have eluded them otherwise" (p. 85). Evidence abounds that an instructor's good listening skills, strong emotional disposition, and commitment to effective teaching-learning transactions are critical to allaying anxieties in adult learners. An emotionally charged instructor tends to be caring, approachable, understands learners' feelings; and is proactive in nipping stressors in the bud before they constitute nuisance to adult learners. According to Wlodkowski, $(1985,1999)$ empathy is the skill that allows instructors to meet adult learners' needs and perceptions for motivating instruction. The more students' needs and expectations are met, the more motivated they are to learn.

According to Rogers (1989), educational research has confirmed that effective instructors of adult learners have these characteristics:

- a warm personality - ability to show approval and acceptance of students;

- $\quad$ social skill - ability to weld the group together and control it without dominating it;

- an 'indirect' manner of teaching which generates and uses learners' ideas;

- organizing ability so that resources are booked, administration is smoothly handled;

- skill in spotting and resolving learner problems;

- enthusiasm - for instance, an animated demeanor, plenty of eye contact, varied voice inflexion. (pp. 88-89)

\subsection{Implications for Institutional Policy in Higher Education}

Despite the significant advances in andragogical principles of teaching adults as different from the youth, some facilitators of adult learning are still grappling with effective ways of motivating adult learners. This deficiency can be demotivating to most students and consequently affect their academic performances. The literature is replete of the fact that "when faculty improve their teaching, students learn more, and their performance on course work improves" (Condon, Iverson, Manduca, Rutz, \& Willett, 2016, p. 125). Since teaching is the "most central of institutional commitments" (Stetar \& Finkelstein, 1997, p. 302), and perhaps because the roles of instructors at colleges and universities "include expert, manager, teacher, evaluator, facilitator, leader, mentor, or instructional designer" (Cranton, 1989, p. 4), it is the onus of the administrators at colleges and universities to review their professional development policy to focus more on enhancing the teaching capability of their faculty. According to Saroyan and Trigwell (2015), "the necessity for improving quality teaching has never been as compelling" (p. 92) as it is today, hence the need for more attention by policy makers in higher education institutions. As claimed by Stetar and Finkelstein (1997), "The opportunities and motivations for faculty and students to focus their energies on 
teaching and learning and the satisfactions each derive from those endeavors are closely tied to the centrality of the academic role in their lives and the strength of their institutional commitments" (p. 302).

The effect of an institutional commitment on students' motivation to learn manifests itself in the quality of instructional delivery by its faculty. Empirically, when administrators satisfy the needs of their faculty, give adequate recognition to their invaluable contributions, and accord them with deserving dignity; the faculty are reciprocally motivated and inclined to keep performing better in their instructional delivery practices. Consequently, this sets the groundswell for student motivation and enhanced academic achievement. Adapting Neila Connors' (2000) metaphor of "If You Don't Feed Teachers, They Eat the Students," it is important for colleges and universities to have "a policy on feeding the instructors." In other words, if we don't motivate instructors, they demotivate the students! The challenge of the metaphor calls on administrators to create a positive collegiate culture and continue to monitor and assess the climate to ensure a conducive working and learning environment for faculty and students, respectively. This means that while focusing on what is best for students, administrators should not overlook the importance of addressing the needs of the instructors teaching the students. That is, administrators should be mindful of taking care of the goose laying the golden eggs! Instructors should be recognized as extraordinary resources and vital components of successful higher education and treated as such. For example, as recommended by Blackburn (1997), colleges and universities should "have an awards ceremony in which a number of faculty are publicly recognized - their pictures appear in the press, an honorarium accompanies a certificate or a plaque" (p. 330). This is a tradition that is worth embracing by all higher education institutions.

In sum, the following are some policy recommendations evolving from this study for higher education administrators as part of the strategies to enhance the quality of instruction of their faculty:

- Make regular professional development on quality teaching compulsory for faculty (full-time and part-time).

- Plan for faculty development workshops on andragogical teaching principles.

- Encourage peer observation and coaching of professional colleagues with guidelines that encourage innovations and creativity.

- Encourage and sponsor faculty membership and subscription to professional associations and journals as a way of enhancing currency of knowledge and skills relating to quality instruction.

- Provide faculty with adequate funding for individual and/or collaborative projects geared toward enhanced instructional delivery.

- Organize orientation and mentor-mentee programs for new faculty members.

- Increase collaboration between faculty and university administration through dialogs geared to increasing quality of instruction (e.g., dialogs around appropriate faculty load, scholarships, and travel incentives, etcetera).

- Recognize faculty for teaching excellence, scholarships, and innovations.

Among other benefits, the culminating impact of strategies to motivate students to learn can also help to improve retention and graduation rates of students in colleges and universities.

\subsection{Implications for Further Research}

Since this study was limited to students in the Master's Program in Educational Leadership at Central Connecticut State University, the finding (that quality instruction is the most valued motivating factor for students in higher education) may not be generalizable to graduate students in different programs at the same university and other colleges and universities. In other words, the finding may not be generalizable from the sample studied to a larger population in different programs. This calls for more studies, across disciplines and programs as well as those involving graduate students with varying characteristics such as academic backgrounds, program backgrounds, cultural backgrounds, socioeconomic status, learning needs, learning styles, level of students in programs, age groups, genders, and personality types. Also important is the need for further research into the implications of the impact of the differences in the frequency and quality of interactions between on-ground and online classes. Another interesting area for future research is the comparative analysis of the quality of instruction between higher education instructors with and without backgrounds in andragogy. 


\section{Conclusion}

This study supports the view that quality instruction is critical to motivating students in higher education and explicates its implications for instructors, administrators, and further research. The recurring theme in the findings of this study is the motivating effect of quality instruction on learning.

For motivational and effective learning purposes, the composite of quality instruction is revealing for instructors in higher education, hence the need for employing instructors with andragogical credentials, content and currency of knowledge, proven technological and organizational skills, resourceful ability and enviable personality characteristics cannot be compromised. Today, a critical source of enhancing quality instruction and student motivation to learn is the use of blended learning which is at the forefront of revolutionizing the teaching and learning transactions in higher education. Indeed, in the face of the prevailing global declining enrollment phenomenon across higher education institutions, there is the compelling reason to invest more in the infrastructure that facilitates the use of blended learning in order to attract more adult learners. This calls for colleges and universities to make quality instruction central to their responsibilities and continually develop workshops for faculty (i.e., both neophytes and veterans) on the use of blended learning and other emerging technological advancements related to teaching and learning.

Given that there is a correlation between students' motivation to learn and the quality of instruction received, Perry's (1991) claim that "Weiner's attribution theory $(1985,1986)$ is particularly relevant to the college classroom because of its primary emphasis on achievement motivation" (p. 49), is valid in this study. In other words, from the perspective of attribution theorists, it is safe to claim that students' level of motivation to learn is greatly influenced by the quality of instruction received and that the higher the quality of instruction, the more likely a student is motivated to learn. Furthermore, if Wiseman and Hunt (2001) are correct in their behaviorism theorist approach to defining motivation as the result of responses to reinforcers either present internally within the student or externally influenced by the teacher, then the importance of the role of both quality of instruction and instructor's dispositional attributes in students' motivation to learn become particularly critical to their success.

Overall, evidence abounds that a student's motivation to learn is piqued by the quality of the instruction received. That is, when the quality of instruction is high, a student's motivation to learn increases. Therefore, this study has particularly espoused the importance of quality instruction as a motivating factor critical to student learning in higher education.

\section{References}

Armstrong, T. (2009). Multiple intelligences in the classroom (3rd ed.). Alexandria, VA: Association for Supervision and Curriculum Development.

Bess, J. L. (Ed.). (1997). Teaching well and liking it: Motivating faculty to teach effectively. Baltimore, MD: John Hopkins University Press.

Blackburn, R. T. (1997). Career phases and their effect on faculty motivation. In J. L. Bess, (Ed.). Teaching well and liking it: Motivating faculty to teach effectively (pp. 72-89). Baltimore, MD: John Hopkins University Press.

Breen, R. \& Lindsay, R. (1999). Academic research and student motivation. Studies in Higher Education, 24(1), 75-79. https://doi.org/10.1080/03075079912331380158

Brookfield, S. (1986). Understanding and facilitating adult learning. San Francisco: Jossey-Bass.

Brookfield, S. D. (2006, fall). Authenticity and power. In P. Cranton. Authenticity in teaching. New Directions for Adult and Continuing Education, 111, 5-16. https://doi.org/10.1002/ace.223

Condon, W., Iverson, E. R., Manduca, C. A., Rutz, C., \& Willett, G. (2016). Faculty development and student learning: Assessing the connections. Bloomington: Indiana University Press.

Connors, N. A. (2000). If you don't feed the teachers, they eat the students: A guide to success for administrators and teachers. Nashville, TN: Incentive Publications.

Cranton, P. (1989). Planning instruction for adult learners. Middleton, OH: Wall \& Emerson.

Cranton, P. (1992). Working with adult learners. Middletown, OH: Wall \& Emerson.

Cranton, P. (1996). Professional development as transformative learning: New perspectives for teachers of adults. San Francisco: Jossey-Bass. 
Creswell, J. W. (2008). Educational Research: Planning, conducting, and evaluating quantitative and qualitative research. Upper Saddle River, NJ: Pearson.

Csikszentmihalyi, M. (1997). Intrinsic motivation and effective teaching: A flow analysis. In J. L. Bess, (Ed.). Teaching well and liking it: Motivating faculty to teach effectively (pp. 72-89). Baltimore, MD: John Hopkins University Press.

D’Avanzo, C., \& Morris, D. (2008, January-February). Investigating your own teaching. Academe, 94(1), 40-44.

Davidson-Shivers, G. V. (2009, Spring). Frequency and types of instructor interactions in online instruction. Journal of Interactive Online Learning, 8(1), 1-40.

Feldman, K. A. (1989). The association between student ratings of specific instructional dimensions and student achievement: Refining and extending the synthesis of data from multisection validity studies. Research in Higher Education, 4, 583-645. https://doi.org/10.1007/BF00992392

Gall, J. P., Gall, M. D., \& Borg, W. R. (2003). Applying educational research: A practical guide. Boston: Allyn \& Bacon.

Goleman, D. (1995). Emotional intelligence: Why it can matter more than IQ. New York: Bantam Books.

Hattie, J. A. C. (2012). Visible learning for teachers: Maximizing impact on achievement. Oxford, UK: Routledge.

Jenkins, A. (2000). Where does geography stand on the relationship between teaching and research? Where do we stand and deliver? Journal of Geography in Higher Education, 24(3), 325-351. https://doi.org/10.1080/713677414

Knowles, M. S. (1980). The modern practice of adult education: From pedagogy to andragogy. New York: The Association Press.

Knowles, M. S. (1984). Andragogy in action. San Francisco: Jossey-Bass.

Knowles, M. S. (1989). The making of an adult educator: An autobiographical journey. San Francisco: Jossey-Bass.

Knowles, M. S., Holton, E. F., \& Swanson, R. A. (2005). The adult learner: The definitive classic in adult education and human resource development. San Diego, CA: Elsevier.

Lindsay, R, Breen, R., \& Jenkins, A. (2002). Academic research and teaching quality: The views of undergraduate and postgraduate students. Studies in Higher Education, 27(3), 309-27. https://doi.org/10.1080/03075070220000699

MacKeracher, D. (2004). Making sense of adult learning. Toronto, Canada: University of Toronto Press.

McMillan, J. H. \& Schumacher, S. (2010). Research in education: Evidence-based inquiry. Boston: Pearson.

Merriam, S. B., Caffarella, R. S., \& Baumgartner, L. M. (2007). Learning in adulthood: A comprehensive guide. San Francisco: Jossey-Bass.

Mujiyanto, J. (2013). Topics in Applied Linguistics. Semarang, Indonesia: Unnes Press.

Perry, R. P. (1990). Introduction to the special section: Instruction in higher education. Journal of Educational Psychology, 82, 183-188. https://doi.org/10.1037/0022-0663.82.2.183

Perry, R. P. (1991). Perceived control in college students: Implications for instruction in higher education. In J. C. Smart (Ed.). Higher Education: Handbook of theory and research, VII (pp. 1-56). New York: Agathon Press.

Project Tomorrow (2011). The new 3E's of education: Enabled, engaged, empowered. How today's students are leveraging emerging technologies for learning. http://www.tomorrow.org/speakup/speakup_data_findings.html.

Rogers, J. (1989). Adult learning. Bristol, PA: Open University Press.

Saroyan, A., \& Trigwell, K. (2015). Higher education teachers' professional learning: Process and outcome. Studies in Educational Evaluation, 46, 92-101.

Schunk, D. H., Pintrich, P. R., \& Meece, J. L. (2008). Motivation in education: Theory, research, and applications. Upper Saddle River, NJ: Pearson.

Sogunro, O. A. (2015). Motivating factors for adult learners in higher education. International Journal of Higher Education, 4(1), 22-37.

Stetar, J. M., \& Finkelstein, M. J. (1997). The meaning of human motivation. In J. L. Bess (Ed.). Teaching well and liking it: Motivating faculty to teach effectively (pp. 287-313). Baltimore, MD: John Hopkins University Press. 
Thompson, M. A., \& Clayton, M. D. (2004). Andragogy for adult learners in higher education. Proceedings of the Academy of Accounting and Financial Studies, 9(1), 107-111.

Tucker, C. R. (2013, March). Technology-Rich Learning: The basics of blended learning. Educational Leadership, 70(6), 57-60.

Walter Gudea, S. (2008). (Ed). Expectations and demands in online teaching: Practical experiences. Hershey, NY: Information Science Publishing, INFOSCI.

Wiseman, D. G., \& Hunt, G. H. (2001). Best practices in motivation and management in the classroom. Springfield, IL: Charles Thomas.

Wlodkowski, R. J. (1985). Enhancing adult motivation to learn: A guide to improving instruction and increasing learner achievement. San Francisco: Jossey-Bass.

Wlodkowski, R. J. (1999). Enhancing adult motivation to learn: A comprehensive guide for teaching all adults. San Francisco: Jossey-Bass.

Wlodkowski, R. J. (2003, summer). Fostering motivation in professional development programs. New Directions for Adult and Continuing Education, 98, 39-47. https://doi.org/10.1002/ace.98

Woodall, D. (2012, May). Blended learning strategies: Selecting the best instructional method. Skillsoft Learning. Retrieved, April 10, 2016.

Ya Ni, A. (2013). Comparing the effectiveness of classroom and online learning: Teaching research methods. Journal of Public Affairs Education, JPAE, 19(2), 199-215. 